\title{
LISENSI PENGUMUMAN LAGU ATAU MUSIK DALAM PERSFEKTIF HUKUM PERDATA
}

\author{
Bernard Nainggolan ${ }^{1}$
}

\begin{abstract}
Abstrak
The right to announce song or music, Which called in international with the performing rights or the public performance right is a part from economic right the creator of song or music. When its parsed, the right to announce consist of broadcast right, demonstrating right, announcing or utters right, as well to communicate song or musci right to the public. If so in announced right song or music bring in economic benefits to the creator of song or music, therefore needs to be given license to the user citizen song or music. However, in giving those license, might be effective, needs to be presence any institution License of principle and Collector Royalty in togetherness, that called as Collective Management Organization (CMO). Practically that has been held this periode in Indonesia, the granting of announcement license song or music is not doing by the creator or the holder copy right, but the State Public Institution (LMK) in blanket license form. So, State Public Institution with handing the representative letter from the creator of song or music giving license to useful song or music, to collect the Royalty, and then to distributing the Royalty to the people who has authority. At the view of private law, the announcement license of song or music is like an agreement what ought to have maded in written form. Its can not consist of rules which is able to harmful the state economic dan can not contain s of many things that contrast with the rule of laws. In other hand, that can be binding to the third side, therefore these license agreement of copy right must be noted in the Ministry of Law and Human Rights Indonesian Republic of Indonesia, the Directorate General of Intelctual Riches. Thereby the announcement of license song or music based on to the Private law include Formal Agreement type and from the management is an Annonymous Agreement (Onbenoemnde contract) or General Agreement type.
\end{abstract}

\section{Keywords: lisensi; pengumuman lagu atau musik}

\section{Pendahuluan}

Hak cipta adalah satu bagian besar dari Hak Kekayaan Intelektual (Intellectual Property Right). Pada awalnya yang disebut dengan Intellectual Property Right (IPR) merupakan pengaturan sekelompok kekayaan intelektual digolongkan dalam dua bagian besar, yaitu kekayaan industri (Industrial Property) dan hak cipta (Copyright). Kekayaan industri terdiri dari Paten (Patents), Merek Dagang (Trademarks), Desain Industri (Industrial Designs), dan kekayaan intelektual kontemporer yang mendapat pengaturan belakangan, yaitu Desain Tata Letak Sirkuit Terpadu, Rahasia Dagang, dan Varietas Tanaman. ${ }^{2}$

\footnotetext{
${ }^{1}$ Dosen Tetap Program Magister Ilmu Hukum UKI, Jakarta

${ }^{2}$ Bernard Nainggolan, Pemberdayaan Hukum Hak Cipta dan Lembaga Manajemen Kolektif, Bandung: PT. Alumni, 2011, hal. 59
}

Kesepakatan internasional tentang perlindun- gan kekayaan industri terwujud dengan lahirnya The Paris Convention for the Protection of Industrial Property (Konvensi Paris) di Paris, Perancis, tahun 1883. Setelah itu, kekayaan intelektual lain, berjenis ciptaan di bidang seni, sastra yang bersifat individual yang disebut hak cipta (copyright) ditambahkan sebagai bagian dari Intellectual Property ${ }^{3}$ dan dilindungi

\footnotetext{
${ }^{3}$ David Bainbridge, Intellectual Property (Financial Times Pitman Publishing, England, 1999), hal. 5: Traditionally, a number of intellectual property rights were known collectively as industrial property. Such rights include patents, trade marks and designs. The description was used in the Paris Convention for the Protec- tion of Industrial Property 1883. Included in this term by implica- tion are the law of confidence and passing off. When other rights such as copyright are added to industrial property the phrase used to describe the entirety of rights is intellectual property and this has become the phrase normally used to the describe these indivi-dual, and sometimes disparate, rights collectively.
} 
secara internasional berdasarkan The Berne Convention for the Protection of Literary and Artistic Works (Konvensi Bern) yang lahir di kota Berne, Jerman, tahun 1886.

HKI dapat diartikan sebagai hak atas kepemilikan terhadap karya-karya yang timbul atau lahir dari kemampuan intelektual seseorang dalam bidang seni, ilmu pengetahuan, dan teknologi. Karya-karya tersebut merupakan kebendaan tidak berwujud yang merupakan hasil kemampuan intelektual manusia dalam bidang seni, ilmu pengetahuan, dan teknologi yang mempunyai nilai-nilai moral dan ekonomi.

Khusus tentang hak cipta, sesuai dengan rumusan undang-undang, hak cipta dipandang sebagai suatu hak yang eksklusif ${ }^{4}$, maka konsekwensinya ada- lah tidak ada pihak lain yang dapat mengambil atau memperoleh manfaat ekonomi dari suatu ciptaan ${ }^{5}$ tanpa ijin dari pencipta ${ }^{6}$ atau pemegang hak ciptanya ${ }^{7}$ yang sah. Dengan kata lain, Hak Cipta adalah hak eksklusif bagi pencipta atau pemegang hak untuk mengumumkan atau memperbanyak ciptaannya atau memberikan izin untuk itu dengan tidak mengurangi pembatasan-pembatasan menurut peraturan perundang-undangan yang berlaku, dari sekian banyak ciptaan yang dilindungi sesuai Undang-Undang RI No. 28 Tahun 2014 Tentang Hak Cipta (untuk selanjutnya disingkat dengan UUHC 2014). ${ }^{8}$

Tulisan ini menitikberatkan pembahasan pada hak cipta atas lagu dan/atau musik, khususnya yang berkaitan dengan hak ekonomi bidang pengumuman (performing right).

\footnotetext{
${ }^{4}$ Pasal 1 angka 1 UU RI No. 28 Tahun 2014 Tentang Hak Cipta menentukan bahwa hak cipta adalah hak eksklusif pencipta yang timbul secara otomatis berdasarkan prinsip deklaratif setelah suatu ciptaan diwujudkan dalam bentuk nyata tanpa mengurangi
}

pembatasan sesuai dengan ketentuan peraturan perundang-undangan.

${ }^{5}$ Ciptaan adalah setiap hasil karya cipta di bidang ilmu pengetahuan, seni dan sastera yang dihasilkan atas inspirasi, kemampuan, pikiran, imajinasi, kecekatan, keterampilan atau keahlian yang diekspressikan dalam bentuk nyata.

${ }^{6}$ Pencipta adalah seorang atau beberapa orang yang secara sendi- risendiri atau bersama-sama menghasilkan suatu ciptaan yang bersifat khas dan pribadi.

${ }^{7}$ Pemegang hak cipta adalah pencipta sebagai pemilik hak cipta, pihak yang menerima hak tersebut secara sah dari pencipta atau pihak lain yang menerima lebih lanjut hak dari pihak yang menerima hak tersebut secara sah.

${ }^{8}$ Menurut Pasal 40 UUHC 2014, ciptaan yang dilindungi adalah a) buku, pamplet, perwajahan karya tulis yang diterbitkan dan semua hasil karya tulis lainnya; b) ceramah, kuliah, pidato dan ciptaan sejenis lainnya; c) alat peraga yang dibuat untuk kepentingan pendidikan dan ilmu pengetahuan; d) lagu dan/atau musik

\section{Permasalahan}

1. Apa hak-hak yang terkandung dalam ciptaan lagu atau musik dan bagaimana pengeksploitasiannya?

2. Bagaimana pelisensian hak mengumumkan di bidang lagu atau musik dalam persfektif hukum perdata?

\section{Tujuan Penulisan}

1. Untuk mengetahui hak-hak yang terkandung dalam ciptaan lagu atau musik;

2. Untuk mengetahui perlisensian hak menggunakan lagu dari perspektif hukum perdata.

\section{Hak Ciptaan Lagu, Musik, dan Pengekploitasiannya}

Secara etimologi, lagu dan musik sebenarnya memiliki perbedaan arti. Lagu adalah suatu kesatuan musik yang terdiri atas susunan pelbagai nada yang berurutan. Setiap lagu ditentukan oleh panjangpendek dan tinggi-rendahnya nada-nada tersebut; di samping itu irama juga memberi corak tertentu kepada suatu lagu?.

Menurut Ensiklopedia Indonesia, sebuah lagu terdiri dari beberapa unsur, yaitu: melodi, lirik, aransemen, dan notasi. Melodi adalah suatu deretan nada yang, karena kekhususan dalam penyusunan menurut jarak dan tinggi nada, memperoleh suatu watak tersendiri dan menurut kaidah musik yang berlaku membulat jadi suatu kesatuan organik. Lirik adalah syair atau kata-kata yang disuarakan mengiringi melodi. Aransemen adalah penataan terhadap melodi.

dengan atau tanpa teks; e). drama, drama musical, tari, koreografi, pewayangan dan pantomin; f). karya seni rupa dalam segala ebntuk seperti lukisan, gambar, ukiran, kaligrafi, seni pahat, patung atau kolase; g). karya seni terapan; h). karya arsitektur; i). peta; j). karya seni batik atau seni motif lain; k). karya fotografi; 1). potert; m). karya sinematografi; n). terjemahan, tafsir, sadu- ran, bunga rampai, basis data, adaptasi, aransemen, modifikasi dan karya lain dari hasil transformasi; 0). Terjemahan, adaptasi, aransemen, transformasi atau modifikasi ekspresi budaya tradisional; p). kompilasi ciptaan atau data, baik dalam format yang dapat dibaca dengan program computer maupun media lainnya; q). kompilasi ekspresi budaya tradisional selama kompilasi ter- sebut merupakan karya yang asli; r). permaninan video, dan; s). program komputer.

${ }^{9}$ Ensiklopedi Indonesia, buku 4, Penerbit PT. Ichtiar Baru - Van Hoeve, Jakarta, tanpa tahun penerbitan, hal. 1940. 
Selanjutnya, notasi adalah penulisan melodi dalam bentuk not balok atau not angka. ${ }^{10}$

Adapun pengertian musik menurut Ensiklopedia Indonesia lebih lanjut adalah seni menyusun suara atau bunyi. Musik tidak bisa dibatasi dengan seni menyusun bunyi atau suara indah semata-mata. Suara atau bunyi sumbang (disonansi) telah lama digunakan, dan banyak komponis modern bereksperimen dengan suara atau bunyi semacam itu. ${ }^{11}$

Dalam kepustakaan hukum hak cipta, istilah yang lazim digunakan untuk menyebutkan lagu atau musik adalah "musical work". Konvensi Bern menyebutkan salah satu "work" yang dilindungi adalah komposisi musik (music compositions) dengan atau tanpa katakata (with or without words) ${ }^{12}$. Dalam UUHC 2014 (penjelasan Pasal 40 ayat (1) ): Yang dimaksud dengan "lagu atau musik dengan atau tanpa teks" diartikan sebagai satu kesatuan karya cipta yang bersifat utuh.

David Bainbridge ${ }^{13}$ membuat pengertian yang sederhana tentang "musical work" dengan mengatakan:

"A musical work is one consisting of music, exclusif of any words or action intended to be song, spoken or performed with music."

Dalam Undang-undang RI No. 19 tahun 2002 tentang Hak Cipta tidak diuraikan dengan tegas apa saja yang menjadi bagian dari Hak Ekonomi Pencipta. Dalam pasal 2 ayat 1 UUHC 2002, hak ekonomi dibagi dalam dua bagian besar, yaitu hak untuk mengumumkan ciptaan dan hak untuk memperbanyak ciptaan (selanjutnya disebut hak mengumumkan dan hak memperbanyak). Sedangkan untuk mengetahui cakupan dari hak mengumumkan dan hak memper-

\footnotetext{
${ }^{10}$ Ibid

11 Ibid

${ }^{12}$ Di dalam Article 2 (1) Bern Convention, disebutkan salah satu "work" yang dilindungi adalah "musical composition with or without words". Tidak ada uraian yang tegas dalam Konvensi Bern tentang apa sesungguhnya "musical composition with or without words" itu. Namun demikian, dapat disimpulkan bahwa ada dua jenis komposisi musik yang dilindungi Konvensi Bern, yaitu musik dengan kata-kata dan musik tanpa kata-kata. Mu- sik dengan kata-kata berarti adalah lagu yang unsurnya terdiri dari melodi, lirik, aransemen, dan notasi, sedangkan musik tanpa katakata adalah musik yang hanya terdiri dari unsur melodi, aransemen, dan notasi.

${ }^{13}$ David Bainbridge, Op.Cit., hal. 50. Dari pengertian yang disampaikan Davis Bainbridge tampak ada tiga unsur karya musik, yaitu musik, syair, dan penampilan musik.
}

banyak dapat dilihat pada pasal 1 UUHC, yang menjelaskan bahwa Pengumuman adalah pembacaan, penyiaran, pameran, penjualan, pengedaran, atau penyebaran suatu Ciptaan dengan menggunakan alat apa pun, termasuk media internet, atau melakukan dengan cara apa pun sehingga suatu Ciptaan dapat dibaca, didengar, atau dilihat orang lain. Selanjutnya, Perbanyakan adalah penambahan jumlah sesuatu Ciptaan, baik secara keseluruhan maupun bagian yang sangat substansial dengan menggunakan bahanbahan yang sama ataupun tidak sama, termasuk mengalihwujudkan secara permanen atau temporer.

Tetapi dalam UUHC 2014, ruang lingkup Hak Ekonomi Pencipta telah diurai dengan jelas. Dalam Pasal 9 ayat (1) ditegaskan, bahwa Pencipta atau Pemegang Hak Cipta memiliki hak ekonomi untuk melakukan: a). penerbitan Ciptaan; b). Penggandaan Ciptaan dalam segala bentuknya; c). penerjemahan Ciptaan; d). pengadaptasian, pengaransemenan, atau pentransformasian Ciptaan; e). Pendistribusian Ciptaan atau salinannya; f). pertunjukan Ciptaan; g). Pengumuman Ciptaan; h). Komunikasi Ciptaan; dan; i). penyewaan Ciptaan.

Ciptaan lagu atau musik yang terdiri atas unsur lagu atau melodi, syair atau lirik, dan aransemennya termasuk notasi yang merupakan kesatuan yang utuh berarti mengandung unsur-unsur hak sebagaimana disebutkan dalam Pasal 9 ayat 1 UUHC 2014 tersebut. Oleh sebab itu, apabila ada orang lain yang bukan pencipta atau pemegang hak cipta yang hendak menerbitkan, menggandakan, menerjemahkan, mengadaptasi, mengaransemen, mempertunjukkan, mengumumkan sebuah lagu atau musik, maka harus terlebih dahulu mendapat izin dari pencipta/pemegang hak cipta lagu atau musik.

Sebuah ciptaan lagu atau musik, agar mendatangkan manfaat ekonomi bagi pencipta tentu harus dieksploitasi. ${ }^{14}$ Kegiatan pengeksploitasian ini bisa dilakukan sendiri oleh pencipta atau memberikan haknya kepada orang lain berdasarkan suatu perjanjian lisensi. ${ }^{15}$ Kegiatan-kegiatan pengekploitasian

\footnotetext{
${ }^{14}$ Tentang exploitation of work, WIPO Glossary, hal. 110, disebutkan: "Use of a work for profit-making purposes by exhibiting, reproduction, distributing or otherwise communicating it to public. The exploitation of works protected by copyright goes hand in hand with the exploitation of authors rights in such works."

${ }^{15}$ Untuk mendapatkan hasil ekonomi yang optimal, pada umum pencipta lagu atau musik menyerahkan pengekploitasian lagu atau music ciptaannya kepada orang lain, seperti kepada publis- her atau produser rekaman.
} 
lagu atau musik, antara lain: merekam, memperbanyak rekaman, mendistribusikan rekaman, mempertunjukkan serta mengumumkan lagu atau musik dengan berbagai cara.

\section{Hak Mengumumkan Ciptaan Lagu atau Musik}

Kegiatan-kegiatan pengekloitasian lagu atau musik yang sudah lazim dan dari kegiatan itu pencipta lagu atau musik mendapat manfaat ekonomi (berupa royalti) adalah perekaman lagu, perbanyakan rekaman lagu, dan pendistribusian atau penjualan rekaman lagu. Biasanya, untuk semua pengeksploitasian ini pencipta lagu atau musik membuat perjanjian lisensi dengan perusahaan rekaman suara, dan dengan demikian pencipta lagu atau musik menerima imbalan materi berupa royalti.

Sebagaimana kita ketahui bersama, bahwa kehidupan manusia tidak terlepas dari menikmati berbagai karya seni, salah satunya mendengarkan lagu atau musik, melalui berbagai media seperti tape recorder, piringan hitam, cakram padat (VCD, DVD, CD), radio, dan televisi. Menikmati karya seni tersebut untuk saat ini tidak sebebas sebelum diberlakukannya UU RI No. 19 Tahun 2002 Tentang Hak Cipta yang diperbaharui dengan UU RI No. 28 Tahun 2014 tentang Hak Cipta dimana setiap orang tidak dengan begitu saja bebas menyanyikan dan memperdengarkan lagu atau musik karya seni orang lain untuk kepentingan ekonomi. Dalam hal ini, ada perlindungan hukum bagi pencipta musik atau lagu untuk menghindari pembajakan karya seni yang berupa musik atau lagu. Perlindungan tersebut sangat dibutuhkan karena banyak pencipta karya seni yang di masa tuanya tidak memperoleh apapun atas hasil karyanya akibat dari pembajakan dan lemahnya perlindungan hukum.

Akan tetapi di luar itu, masih ada kegiatan seperti: menyiarkan lagu atau musik (melalui media radio, televisi, dan internet), mempertunjukkan lagu atau musik secara live (dalam bentuk konser), dan mengumumkan lagu, memutar atau memperdengarkan lagu ke publik di tempat-tempat hiburan, restoran, dan mall.
Seyogianya, hal itu adalah hak eksklusif pencipta lagu. Hak yang demikian, secara internasional disebut dengan the performing rights atau the public performance right. Di Indonesia, hak tersebut dalam Undang-undang Hak Cipta yang lama disebut hak mengumumkan, dan berdasarkan Pasal 9 ayat (1) UUHC 2014 diurai menjadi hak ekonomi untuk melakukan pertunjukan ciptaan, pengumuman ciptaan, dan komunikasi ciptaan.

Bagaimanakah para pencipta lagu mendapatkan manfaat ekonomi dari hak mengumumkan itu? Dalam hal ini untuk mewakili pencipta lagu atau musik itu, maka muncullah sebuah lembaga yang disebut dengan Collective Management Organization atau Collecting Society, yang dalam UUHC 2014 disebut dengan Lembaga Manajemen Kolektif (LMK).

Kehadiran LMK ini bagi pencipta lagu atau musik serta pemegang hak terkait sangat penting. Di berbagai negara, lembaga itu telah berhasil memberi penghasilan ekonomi yang sangat besar bagi pencipta dan pemegang hak terkait. Namun demikian, di Indonesia bukan hanya keberadaan LMK yang masih belum populer, bahkan keberadaan hak mengumumkan (performing right) dari pencipta dan pemegang hak terkait pun masih rancu dan debatable. Masih banyak anggota masyarakat yang belum menerima bahwa untuk memperdengarkan lagu di rumah makan, di tempat hiburan, dan lain-lain tempat umum harus mendapat lisensi dan membayar royalti.

\section{Lisensi untuk Penggunaan Lagu atau Musik (Menyangkut Performing Right)}

Dalam Pasal 1 angka 20 UUHC 2014 disebutkan, Lisensi adalah izin tertulis yang diberikan oleh Pemegang Hak Cipta atau Pemilik Hak Terkait kepa- da pihak lain untuk melaksanakan hak ekonomi atas Ciptaannya atau produk Hak Terkait dengan syarat tertentu.

Copinger dan Skone James, memberikan pengertian lisensi sebagai berikut:

"Licenses, is provided that copyright is infringed by any person, who, not being owner of the copyright and without the license of the owner thereof, does any of acts restricted by such copyright. 
Licenses provides for sub-licenses by stating that, where the doing of anything is authorized by the grantee of a license, or a person deriving title from the grantee, and it is within the term (including any implied terms) of the licence for him to authorize it, il shall, for the purposes of the Act, be takenb to be done with the licence of grantor and of every other person (if any) upon whom the licence in binding. $" 16$

WIPO Glossary of Terms of The Law of Copyright and Neighboring Rights menggambarkan hakikat lisensi:

"Generally understood in the field of copyright as the authorization (permission) given by the author or other owner of copyright (licensor) to the user of the work (licensee) to use it in a manner and according to condition agreed upon between them in the pertinent contract (licensing agreement). Unlike an assignment, a license does not transfer ownership; it only constitutes a right or rights to use the work under the copyright in it, which remain with the licensor, though restricted according to the scope of the license granted. The license is either exclusive or non-exclusive; in the latter case, the owner of the copyright may lawfully grant similar licenses to other licensees too. Often the licensee also obtains the right to exploit his license by allowing othjer persons to use the work correspondingly (sub-licenses). Copyright conventions and national copyright laws may provide for compulsory licenses and statutory licenses in special cases. " 17

Pada umumnya lisensi diberikan berdasarkan perjanjian tertulis, jangka waktu lisensi ditentukan, dan biasanya diikuti dengan pemberian royalti oleh penerima lisensi kepada pemberi lisensi. Royalti adalah imbalan atas pemanfaatan Hak Ekonomi suatu Ciptaan atau Produk Hak Terkait yang diterima oleh pencipta atau pemilik hak terkait (Pasal 1 angka 21 UUHC 2014).

Berdasarkan ketentuan Pasal 81 UUHC 2014, bahwa bilamana pencipta, pemegang hak cipta atau

\footnotetext{
${ }^{16}$ Copinger and Skone James, Copyright, Eleventh Edition, Sweet \& Mawell, Londong, 1971, hal. 165.

${ }^{17}$ WIPO Glossary of Terms of The Law of Copyright and Neigboring Rights, Geneva, Published by WIPO, 1980, hal. 142. Bandingkan dengan pengertian lisensi menurut Pasal 1 nomor 14 Undang-undang No. 19 Tahun 2002 tentang hak Cipta, bahwa lisensi adalah izin yang diberikan oleh Pemegang Hak Cipta atau Pemegang Hak Terkait kepada pihak lain untuk mengumumkan dan/atau memperbanyak Ciptaannya atau produk Hak Terkaitnya dengan persyaratan tertentu.
}

pemegang hak terkait sudah melisensikan hak-hak ekonominya sebagaimana disebut dalam Pasal 9 ayat (2); Pasal 23 ayat (2); Pasal 24 ayat (2); dan Pasal 25 ayat (2), maka pencipta, pemegang hak cipta atau pemegang hak terkait pada hakikatnya tidak dapat lagi melaksanakan sendiri hak-haknya itu atau melisensikan ulang kepada pihak ketiga, kecuali diperjanjikan lain.

Ada beberapa hal yang dilarang dalam pembuatan lisensi sebagaimana disebut dalam Pasal 82 UUHC 2014, yaitu:

1. Perjanjian Lisensi dilarang memuat ketentuan yang mengakibatkan kerugian perekonomian Indonesia.

2. Isi perjanjian Lisensi dilarang bertentangan dengan ketentuan peraturan perundang-undangan.

3. Perjanjian Lisensi dilarang menjadi sarana untuk menghilangkan atau mengambil alih seluruh hak Pencipta atas Ciptaannya (termasuk hak moral). Dari ketentuan Pasal 83 UUHC 2014 dapat diketahui bahwa:

1. Perjanjian Lisensi harus dicatatkan dalam daftar umum perjanjian Lisensi Hak Cipta dengan dikenai biaya.

2. Perjanjian Lisensi yang tidak memenuhi ketentuan Pasal 82 UUHC (larangan dalam pembuatan lisensi) tidak dapat dicatat dalam daftar umum perjanjian Lisensi.

3. Perjanjian Lisensi yang tidak dicatat dalam daftar umum tidak mempunyai akibat hukum terhadap pihak ketiga.

4. Ketentuan lebih lanjut mengenai tata cara pencatatan perjanjian Lisensi diatur dengan Peraturan Pemerintah.

Dimanakah pentingnya perjanjian lisensi dicatatkan dalam daftar umum perjanjian lisensi dan mengapa hal itu diharuskan? Menurut penulis, hal ini adalah demi kepentingan umum, untuk menghindarkan terjadinya pelisensian hak cipta atau hak terkait berulangkali.

Akan tetapi bunyi Pasal 83 ayat (3) yang menyatakan bahwa Perjanjian Lisensi yang tidak dicatat dalam daftar umum tidak mempunyai akibat hukum terhadap pihak ketiga, menurut penulis tidakrelevan. Sebab memang, perjanjian tertulis (temasuk perjanjian lisensi hak cipta atau hak terkait) hanya mengikat bagi para pihak yang termasuk dalam perjanjian tersebut. 
Lisensi pengumuman (performing licenses) ialah bentuk izin yang diberikan oleh pemegang hak cipta bagi lembaga-lembaga penyiaran seperti televisi, radio, konser dan lain sebagainya. Setiap kali sebuah lagu ditampilkan atau diperdengarkan kepada umum untuk kepentingan komersial, penyelenggara siaran tersebut berkewajiban membayar royalti kepada si pencipta lagunya. Pemungutan royalti perfoming rights ini umumnya dikelola atau ditangani oleh sebuah lembaga administrasi kolektif hak cipta (Collective Administration of Copyright) atau Collecting Society atau yang disebut Lembaga Manajemen Kolektif (LMK).

Dalam kenyataannya, tidak mungkin pemegang hak cipta pertama memantau penggunaan setiap karya-karyanya pada setiap kesempatan di negara tertentu, apalagi di wilayah asing. Pemegang hak cipta tidak akan dapat dalam praktek memberi lisensi satu demi satu kepada pengguna lagu atau musik (user) dan mengumpulkan royaltinya, mengingat banyaknya pengguna potensial yang perlu dibuatkan lisensi di wilayah yang sangat luas (di negara tertentu dan di seluruh dunia).

Pengguna lagu pun dalam posisi yang sama. Suatu badan usaha, seperti restoran, jika ingin memutar musik latar (back-ground music) di restoran, atau

jika stasiun siaran menyiarkan musik, jika tidak ada kerangka manajemen kolektif, lisensi terpisah akan diperlukan untuk setiap pertunjukan atau penyiaran karya. Dalam hal stasiun siaran, ribuan lagu disiarkan melalui udara setiap tahun. Ini akan sangat sulit, jika bukan tidak mungkin, untuk pengguna tersebut untuk menemukan semua pemilik hak dan bernegosiasi dengan mereka masing-masing untuk mendapat lisensi secara terpisah untuk penggunaan karya yang diinginkan.

Dengan demikian, bagaimana pencipta lagu memperoleh hak-hak ekonominya dari pengekploitasian ciptaannya dan bagaimana supaya pengguna lagu dapat dengan mudah menggunakan lagu tanpa melanggar hak cipta? Permasalahan pengadmistrasian hak ekonomi atau pengumpulan royalti itulah yang ditangani secara seksama oleh lembaga pemungut royalty atau LMK atau Collective Management Organization. Organisasi-organisasi inimenyederhanakan proses negosiasi dalam mengelola hak-hak anggota mereka, dan bertindak sebagai titik kontak tunggal untuk pemberian lisensi dan pembayaran royalti berdasarkan lisensi penggunaan karya musik (blanket license ${ }^{18}$ ), baik untuk pertunjukan maupun penyiaran. Jadi, LMK melayani dan menjembatani kepentingan pencipta lagu dan pengguna (user) lagu. ${ }^{19}$

Dengan blanket license, para pengguna karya memungkinkan untuk menggunakan karya apapun dalam repertoar yang dikelola oleh LMK. Penerapan blanket lisence jauh lebih efektif daripada lisensi terpisah. Dalam hal ini LMK tidak lagi harus memeriksa karya mana yang dipertunjukkan atau digunakan pada setiap kesempatan. Sebaliknya LMK hanya memeriksa apakah blanket lisence telah diterapkan. Dalam kasus tertentu, ada jenis lain dari lisensi yang diterapkan LMK, misalnya "lisensi per acara". ${ }^{20}$

Tentang royalti yang dikumpulkan, LMK lebih lanjut mendistribusikannya kepada anggota atas dasar penggunaan karya-karya mereka. LMK mendistribusikan royalti ini kepada anggota mereka setelah dikurangi biaya administrasi.

\section{Lisensi Pengumuman Musik dan Lagu dalam Persfektif Hukum Perdata}

Dari segi hukum perdata, suatu lisensi adalah suatu perjanjian antara pemberi lisensi dengan penerima lisensi untuk jangka waktu tertentu dan memuat

\footnotetext{
${ }^{18}$ Bryan A. Garner, Black's Law Dictionary, Eight Edition, Thomson-West, hal. 938, merumuskan "Blanket License" adalah $A$ license granted by a performing rights society, such as ASCAP or $B M I$, to use all works in the society's pertfolio in exchange for a fixed percentage of the user's revenues.

${ }^{19}$ Tentang Lembaga Manajemen Kolektif ini, Rancangan Undangundang tentang Hak Cipta baru yang akan menggantikan UUHC 2002 atau UUHC Amandemen, menjelaskan peran pentingnya, sebagai berikut: "Lembaga Manajemen Kolektif memiliki peran yang cukup penting dalam pengelolaan hak ekonomi Pencipta dan Pemegang Hak Terkait, sehingga keberadaannya sangat dibutuhkan oleh masyarakat. Saat ini di Indonesia telah ada beberapa Lembaga Manajemen Kolektif yang secara formal belum diatur dalam Undang-undang Hak Cipta. Hal inilah yang mendorong perlunya pengaturan mengenai Lembaga Manajemen Kolektif agar dalam prakteknya sesuai dengan hukum yang berlaku di bidang Hak Cipta dan Hak Terkait.

${ }^{20}$ Selain blanket license dan "lisensi per acara" juga dikenal lisensilisensi lain di bidang hak cipta, seperti "shrinkwrap licenses" dan "clickwrap agreement". Richard Stim, Op.Cit., hal. 240, menjelaskan tentang dua lisensi tersebut: Some EULAs are known as "shrinkwrap licenses" because - at least in the early days of software production - the user would consent to the EULA (visible on the back of the package) by breaking the box's shrinkwrap. A user who proceeds to use the program is deemed to accept the terms. A user who doesn't want to accept the terms can return the program to the manufacturer for a refund. Another type of EULAS is known as a "clickwrap agreement," since the users must click to accept the conditions before accesing a website or using
} software. 
hak dan kewajiban tertentu, sehingga merupakan perbuatan hukum yang menimbulkan hak dan kewajiban

bagi para pihak, dan karenanya, pemberian lisensi dari pemegang hak cipta lagu dan/atau musik kepada penerima lisensi adalah tunduk kepada hukum perjanjian sebagaimana diatur dalam Buku III KUHPer-

data tentang verbintennis sebagai ketentuan umum dan UUHC sebagai ketentuan khusus (lex specialis).

Perjanjian lisensi tidak secara khusus diatur dalam Bagian Khusus buku III KUHPerdata, sehingga dengan demikian perjanjian lisensi termasuk dalam jenis perjanjian tidak bernama (onbenoemnde contract atau innominaat contract atau perjanjian umum) sebagai lawan daripada perjanjian bernama (benoemnde contract atau nominaat contract atau perjanjian khusus) ${ }^{21}$.

Mariam Darus Badrulzaman ${ }^{22}$ mengemukakan bahwa perjanjian bernama yang disebut sebagai perjanjian khusus adalah perjanjian yang mempunyai nama sendiri. Maksudnya adalah bahwa perjanjianperjanjian tersebut diatur dan diberi nama oleh pembentuk undang-undang berdasarkan titel yang paling banyak terjadi sehari-hari. Perjanjian khususterdapat dalam bab V s.d. XV KUHPerdata. Sedangkan perjanjian tidak bernama yang disebut sebagai perjanjian umum adalah perjanjian-perjanjian yang tidak diatur dalam KUHPerdata, tetapi terdapat dalam masyarakat. Jumlah perjanjian ini tidak terbatas. Lahirnya perjanjian ini dalam praktek adalah berdasarkan asas kebebasan mengadakan perjanjian atau partij otonomy yang berlaku dalam hukum perjanjian. Salah satu contoh dari perjanjian umum adalah perjanjian sewa beli.

J. Satrio memberikan pengertian yang luas daripada pengertian kedua jenis perjanjian ini, dengan mengemukakan bahwa perjanjian bernama ialah perjanjian-perjanjian yang dikenal dengan nama tertentu dan mempunyai pengaturannya secara

\footnotetext{
${ }^{21}$ Pembagian jenis perjanjian menjadi perjanjian berna- ma dan perjanjian tidak bernama didasarkan kepada pasal 1319 KUHPerdata yang menentukan bahwa semua perjanjian baik yang mempunyai suatu nama khusus, maupun yang tidak terke- nal dengan suatu nama tertentu, tunduk kepada peraturan-peratu- ran umum yang termuat di dalam bab ini dan bab yang lalu.

${ }^{22}$ Mariam Darus Badrulzaman, KUHPerdata Buku III Hukum Perikatan Dan Penjelasan, Bandung: Alumni 1983, hal. 91.
}

khusus dalam Undang-Undang, yaitu yang terdapat dalam titel V s/d XIX buku III B. W, dalam KUHD dan didalam perundang-undangan yang lain. Dengan demikian sekarang kita tahu, bahwa perjanjian tidak bernama adalah perjanjian-perjanjian yang belum mendapat pengaturannya secara khusus dalam Undang-Undang ${ }^{23}$.

Permasalahannya adalah apakah perjanjian lisensi bidang performing right adalah sah menurut hukum sedangkan perjanjian tersebut tidak diatur secara khusus dalam bagian khusus buku III KUHPerdata? Keabsahan lisensi sebagai suatu perjanjian sekalipun tidak diatur secara khusus dalam buku III KUHPerdata didasarkan kepada asas kebebasan berkontrak (partij autonomie) ${ }^{24}$ sebagaimana terdapat dalam pasal 1338 ayat (1) KUHPerdata ${ }^{25}$, yang berkaitan erat dengan isi perjanjian, yaitu kebebasan menentukan "apa" dan "siapa" perjanjian itu diadakan. Perjanjian yang dibuat sesuai dengan pasal 1320 KUHPerdata ini mempunyai kekuatan mengikat.

Dalam sistem hukum perdata, kebebasan berkontrak ia dibatasi dengan hak asasi dan kewajiban asasi, yang menurut hukum perdata dikenal dengan undang-undang, ketertiban umum dan kesusilaan (pasal 1337 KUHPerdata). Asas kebebasan berkontrak bukanlah berarti tidak terbatas, melainkan dibatasi oleh tanggung jawab para pihak sehingga asas kebebasan berkontrak sebagai suatu asas yang diberi sifat sebagai suatu asas kebebasan berkontrak yang bertanggung jawab. Asas inilah yang mendukung kedudukan yang seimbang diantara para pihak, antara kreditur dan debitur, sehingga sebuah perjanjian stabil dan memberikan keuntungan bagi kedua belah pihak yang mengadakan perjanjian.

Sebagaimana rumusan dalam Pasal 1338 ayat (1)

\footnotetext{
${ }^{23}$ J. Satrio, Hukum Perjanjian, Bandung: Citra Aditya Bakti, 1992, hal. 117.

${ }^{24}$ Asas kebebasan berkontrak mengandung makna bahwa setiap anggota masyarakat diberikan kebebasan yang seluas-luasnya untuk membuat berbagai jenis perjanjian dalam bentuk dan berisi apapun juga. Batasan terhadap asas kebebasan berkontrak sedemikian adalah pasal 1320 KUHPerdata, yaitu perjanjian yang dibuat secara sah. Secara khusus perjanjian tersebut tidak boleh bertentangan dengan undang-undang, ketertiban umum dan kesusilaan baik dalam masyarakat (vide pasal 1337 KUHPerdata).

${ }^{25}$ Pasal 1338 ayat (1) KUHPerdata menentukan bahwa semua perjanjian yang dibuat secara sah berlaku sebagai undang-un- dang bagi mereka yang membuatnya.
} 
KUHPerdata sebagai dasar hukum pengaturan asas kebebasan berkontrak, dapat diketahui bahwa keberadaan asas kebebasan berkontrak tersebut bukanlah suatu yang berdiri sendiri melainkan tergantung kepada sahnya suatu perjanjian sebagaimana ditentukan dalam Pasal 1320 KUHPerdata yaitu:

\section{a. Sepakat mereka yang mengikatkan dirinya.}

Sepakat yang dimaksudkan disini adalah bahwa para pihak yang membuat perjanjian telah sepakat atau ada persesuaian kemauan atau saling menyetujui kehendak masing-masing yang dilahirkan oleh para pihak dengan tiada paksaan, kekeliruan dan penipuan. Menurut pasal 1321 KUHperdata, suatu sepakat dinyatakan tidak sah apabila diberikan dengan adanya kekhilafan, penipuan dan/atau paksaan.

Pemberian kesepakatan dalam suatu perjanjian dapat dilakukan, baik secara tegas maupun diamdiam (implied). Secara tegas dapat dilakukan dengan memberikan pernyataan, "setuju”, "ok" dan sebagainya yang menunjukkan persetujuannya, termasuk pemberian dan/atau pembubuhan tanda tangan pada suatu perjanjian yang dibuat secara tertulis.

Dalam kaitannya dengan perjanjian lisensi di bidang performing right, bentuk kesepakatan para pihak ternyata melalui penanadatanganan perjanjian lisensi dan/atau pembayaran royalty oleh para pengguna (user) yang diikuti dengan pemberian izin (lisensi) pengumuman lagu dan/atau musik dari pencipta atau pemegang hak cipta, sehingga menurut hukum kesepakatan yang diberikan para pihak dalam suatu perjanjian lisensi dilakukan secara tegas.

\section{b. Kecakapan bertindak dalam hukum.}

Cakap (bekwaam) merupakan syarat umum untuk dapat melakukan suatu perbuatan hukum yang sah. Undang-Undang tidak menentukan siapa yang disebut cakap untuk membuat suatu perjanjian, melainkan sebaliknya secara negatif melalui pasal 1330 KUHPerdata menentukan pihak-pihak tertentu yang tidak cakap untuk membuat perjanjian, yaitu: a). Orang-orang belum dewasa; b). Mereka yang ditaruh di bawah pengampuan. c). Orang-orang perempuan dalam hal-hal yang ditetapkan oleh undang-undang dan pada umumnya semua orang kepada siapa undang-undang telah melarang membuat persetujuanpersetujuan tertentu.

Dalam kaitannya dengan perjanjian lisensi lagu dan/atau musik bidang performing right, yang menjadi para pihak adalah pencipta atau pemegang hak cipta sebagai pemberi lisensi dan para pelaku usaha sebagai penerima lisensi. Para pelaku usaha dimaksud, baik badan usaha berbadan hukum maupun badan usaha tidak berbadan hukum, yang dalam melakukan penandatanganan dan/atau kesepakatan dalam suatu perjanjian lisensi diwakili oleh pengurusnya yang sah menurut hukum. Kewenangan pemegang hak cipta untuk membuat dan menandatangani perjanjian lisensi serta memberikan izin kepada para pelaku usaha sebagai user adalah didasarkan kepada surat kuasa yang diberikan oleh para pencipta kepada pemegag hak cipta, dalam hal ini LMK, seperti misalnya Yayasan Karya Cipta Indonesia (YKCI).

\section{c. Adanya hal tertentu.}

Suatu hal tertentu dimaksudkan adalah objek suatu perjanjian yang menurut pasal 1333 KUHPer-

data, barang yang menjadi objek perjanjian harus tertentu setidak-tidaknya dapat ditentukan jenisnya, sedangkan jumlahnya tidak perlu ditentukan asalkan saja kemudian dapat ditentukan atau diperhitungkan. Barang-barang yang dapat dijadikan objek perjanjian hanyalah barang-barang yang dapat diperdagangkan.

Dalam kaitannya dengan perjanjian lisensi lagu dan/atau musik bidang performing right, maka adapun yang menjadi objek dari perjanjian tersebut adalah karya cipta lagu dan/atau musik yang menurut undang-undang merupakan bagian dari suatu benda bergerak yang berwujud dan tidak ada larangan menurut undang-undang untuk dijadikan sebagai objek suatu perjanjian.

\section{d. Adanya suatu sebab yang halal}

Undang-undang tidak menjelaskan apa yang dimaksud dengan sebab (oorzak, causa). Menurut ju- 
risprudensi yang ditafsirkan sebagai causa adalah isi atau maksud dari perjanjian, sehingga tidak ada kaitannya dengan ajaran sebab akibat (kausalitas). Pengertian sebab dalam hal ini, adalah isi perjanjian itu sendiri yang menggambarkan tujuan yang ingin dicapai oleh pihak-pihak. Menurut undang-undang, causa yang halal adalah apabila tidak dilarang oleh undangundang, tidak bertentangan dengan ketertiban umum dan kesusilaan (pasal 1337 KUHPerdata).

Dalam kaitannya dengan perjanjian lisensi hak cipta lagu dan/atau musik bidang performing right, isi perjanjian adalah pihak yang satu (penerima lisensi) menghendaki diberikannya izin pengumuman atau penggunaan karya cipta lagu dan/atau musik dan pihak lainnya (pencipta atau pemegang hak cipta) menghendaki sejumlah uang tertentu sebagai royalti (lisensi fee).

Dengan memperhatikan pengaturan lisensi dalam UUHC, maka keabsahan suatu perjanjian lisensi lagu dan/atau musik bidang performing right, tidak hanya tergantung kepada persyaratan yang ditetapkan dalam Pasal 1320 KUHPerdata melainkan juga tergantung kepada syarat yang ditetapkan dalam UUHC, yaitu bahwa perjanjian lisensi harus dibuat secara tertulis dan harus dicatatkan di Kementerian Hukum dan HAM Republik Indonesia, Direktorat Jenderal Kekayaan Intelektual.

\section{Kesimpulan}

1. Untuk mendapatkan manfaat ekonomi dari hak mengumumkan lagu atau musik, maka pencipta lagu atau musik harus memberi lisensi kepada pengguna lagu atau music (user). Tetapi pemberian lisensi itu tidak dilakukan secara langsung, melainkan oleh sebuah lembaga yang disebut dengan Collecting Society atau Lembaga Manajemen Kolektif (LMK). Jadi LMK yang mengelola pemberian lisensi kepada user, memungut royalty, dan selanjutnya memdistribusikan royalty kepada yang berhak.

2. Dalam persfektif hukum perdata, pembuatan lisensi pengumuman (performing right) lagu atau musik tidak hanya berdasarkan Pasal 1320 KUHPerdata dan karenanya perjanjian lisensi termasuk jenis perjanjian formal, yang harus dibuat dalam bentuk yang tertentu, yaitu tertulis. Dari segi pengaturannya, perjanjian lisensi termasuk dalam jenis perjanjian tidak bernama (onbenoemde contract).

\section{Saran}

1. Untuk mendukung perlindungan hak cipta di Indonesia, khususnya perlindungan hak cipta lagu atau musik, maka pemerintah harus mendukung LMK yang ada, baik dengan regulasi maupun fasilitas. Sebab tanpa adanya LMK yang baik dan efektif, akan sulit terlindungi hak ekonomi pencipta lagu atau musik khususnya dibidang performing right.

2. Pemerintah perlu mengawasi pemberian lisensi oleh LMK kepada user (pengguna lagu atau musik), selain untuk kepentingan pencipta lagu atau music, juga sebagai alat evaluasi sejauh mana masyarakat, khususnya pengguna lagu atau musik menghargai hak pencipta dan mentaati ketentuan perundang-undangan di bidang hak cipta.

\section{DAFTAR PUSTAKA}

Bryan A. Garner, Black's Law Dictionary, Eight Edition, Thomson-West

Copinger and Skone James, Copyright, Eleventh Edition, Sweet \& Mawell, London, 1971

David Bainbridge, Intellectual Property, England: Financial Times Pitman Publishing, 1999

Direktorat Jenderal Hak Kekayaan Intelektual Departemen Hukum Dan HAM RI, Buku Panduan Hak kekayaan Intelektual, Tangerang, 2008

Ensiklopedi Indonesia, buku 4, Jakarta: Ichtiar Baru - Van Hoeve, tanpa tahun

Marian Badrulzaman Darus, KUHPerdata Buku III Hukum Perikatan dan Penjelasan, Bandung, PT. Alumni 1983

Bernard Nainggolan, Pemberdayaan Hukum Hak Cip-ta dan Lembaga Manajemen Kolektif, Bandung: Alumni, 2011 
J. Satrio, Hukum Perjanjian, Bandung: Citra Aditya Bakti, 1992

WIPO Glossary of Terms of The Law of Copyright and Neigboring Rights, Geneva, Published by WIPO, 1980 